\title{
Up-regulation of stromal cell-derived factor-1 $\alpha$ and its receptor CXCR4 expression accompanied with epithelial-mesenchymal transition in human oral squamous cell carcinoma
}

\author{
MASAYUKI TAKI ${ }^{1}$, KOICHIRO HIGASHIKAWA $^{1}$, SHINGO YONEDA ${ }^{1}$, SHIGEHIRO ONO ${ }^{1}$, \\ HIDEO SHIGEISHI $^{1}$, MASARU NAGAYAMA ${ }^{2}$ and NOBUYUKI KAMATA ${ }^{1}$ \\ ${ }^{1}$ Department of Oral and Maxillofacial Surgery, Division of Cervico-Gnathostomatology, Graduate School of \\ Biomedical Sciences, Hiroshima University, 1-2-3 Kasumi, Minami-ku, Hiroshima 734-8553; ${ }^{2}$ Department \\ of Oral and Maxillofacial Surgery, Institute of Health Biosciences, University of Tokushima \\ Graduate School, 3-18-15 Kuramoto-cho, Tokushima 770-8504, Japan
}

Received September 11, 2007; Accepted December 14, 2007

\begin{abstract}
Stromal cell-derived factor $1 \alpha(\mathrm{SDF}-1 \alpha)$ and its receptor CXCR4 have been implicated in the tumorigenesis, proliferation, and lymph node metastasis of cancer. Here, we report that highly invasive squamous cell carcinoma (SCC) cells with a spindle cell morphology show a strong expression of both SDF-1 $\alpha$ and CXCR4. CXCR4 expression and cell migratory activity were further up-regulated by treatment with SDF- $1 \alpha$ or TGF- $\beta 1$ in these cells. When epithelialmesenchymal transition (EMT) was induced by Snail overexpression in SCC cells with an epithelial phenotype, an increased expression of SDF- $1 \alpha$ was observed. Furthermore, SDF- $1 \alpha$ and TGF- $\beta 1$ up-regulated the expression of CXCR4 and cell migratory activity in these cells. These results indicate that SDF- $1 \alpha$ and CXCR4 expressions are possible markers of highly-invasive SCC and regulated by EMT.
\end{abstract}

\section{Introduction}

Chemokines organize a superfamily of chemotactic cytokines that possesses a wide range of biological activities, including the regulation of leukocyte trafficking, homing of $\mathrm{T}$ - and B-lymphocytes, cytoskeletal rearrangement, and adhesion to extracellular matrix molecules (1-3). They are locally produced in the tissues and act on various cells through selective membrane-bound G-protein-coupled receptors. The CC chemokines, RANTES, and macrophage inflammatory protein-1 $\alpha$ (MIP-1 $\alpha)$ are ligands for CCR5, and the CXC

Correspondence to: Dr Nobuyuki Kamata, Department of Oral and Maxillofacial Surgery, Division of Cervico-Gnathostomatology, Graduate School of Biomedical Sciences, Hiroshima University, 1-2-3 Kasumi, Minami-ku, Hiroshima 734-8553, Japan E-mail: nokam@hiroshima-u.ac.jp

Key words: oral squamous cell carcinoma, epithelial-mesenchymal transition, SDF-1 $\alpha, \mathrm{CXCR} 4$ chemokine, stromal cell-derived factor-1 (SDF-1), is known to be a ligand for CXCR4 and regulate T-cell activation. Expression of SDF-1 is enhanced by stimulation with tumor necrosis factor- $\alpha(\mathrm{TNF}-\alpha)$, interferon- $\gamma(\mathrm{IFN}-\gamma)$, and transforming growth factor- $\beta$ (TGF- $\beta$ ) in fibroblasts (4). Furthermore, there is accumulating evidence that the chemokines and their receptors regulate the motility and metastasis of cancer cells. Especially, SDF-1 $\alpha$ and CXCR 4 have been reported to be important mediators of cancer progression (5-8). CXCR4 inhibition can affect tumor cell dissemination in non-Hodgkin's lymphoma and melanoma $(9,10)$ and cancer cells expressing CXCR4 invade the extracellular matrix and metastasize to organs expressing SDF-1 $1 \alpha(11)$.

On the other hand, the increased motility and invasiveness of cancer cells have been implicated in epithelial-mesenchymal transition (EMT), a phenomenon occurring during embryonic development including gastrulation and neuro-epithelium formation (12-15). During the process of EMT, the loss of E-cadherin expression, an adhesion molecule of epithelial cells, is one of the key steps towards the invasive phenotype $(16,17)$. Several transcriptional factors including zinc-finger proteins of the Snail/Slug family $(18,19)$, SEF1/ZEB1 (20), SIP-1/ZEB2 (21), and E12/E47 (22), that contain the basic helix-loop-helix motif, have been reported to be involved in this repression through binding to the E-box localized in the promoter of E-cadherin. Furthermore, TGF- $\beta 1$ has also been reported to regulate EMT in several cell types (23-25).

In the present study, we analyzed SDF-1 $\alpha$ and CXCR4 expressions in SCC cells with both epithelial and mesenchymal phenotypes and in EMT-induced cells by Snail-overexpression. We found that SDF- $1 \alpha$ and CXCR4 expressions in SCC cells were up-regulated in conjunction with increased activities of migration by EMT.

\section{Materials and methods}

Cells and cell culture. The human oral SCC cell lines, OM-1, HOC719-PE, HOC719-NE, HOC313, their stable Snail over- 
A
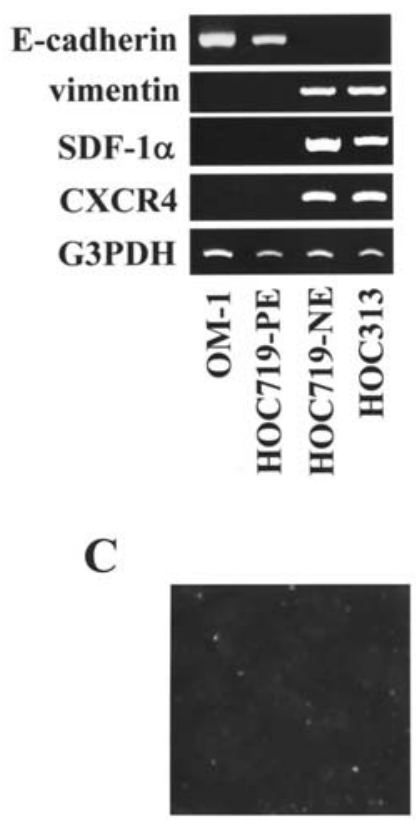

a

D
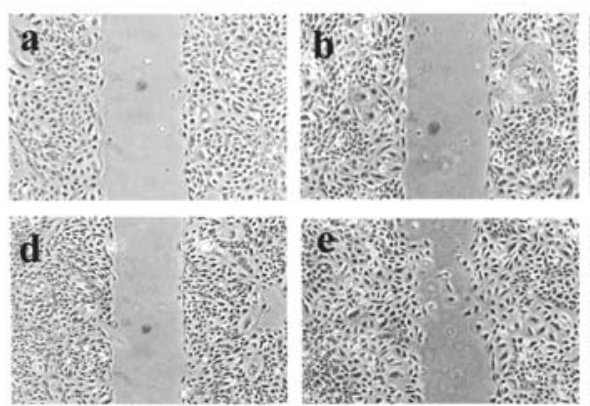

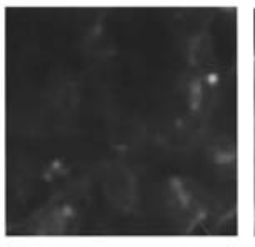

b

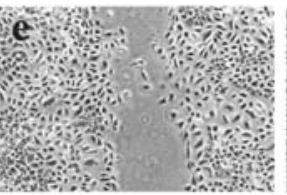

B

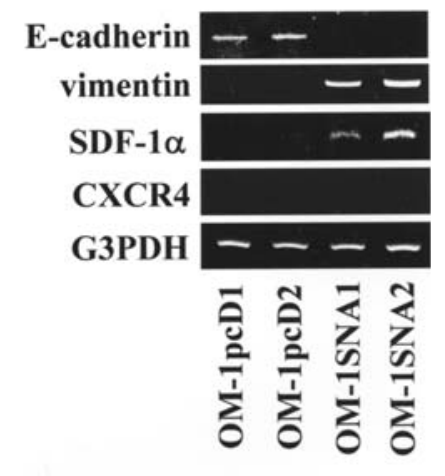

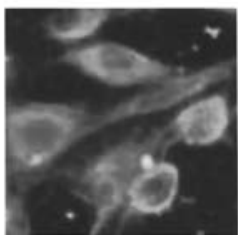

c

Figure 1. Expressions of SDF-1 $\alpha$ and CXCR4 in SCC cells. (A) E-cadherin, vimentin, SDF-1 $\alpha$, and CXCR4 expressions in SCC cells with epithelial (OM-1, HOC719-PE) and mesenchymal (HOC719-NE, HOC313) phenotypes. Total-RNAs were isolated from SCC cells and analyzed by RT-PCR. (B) Expression of mRNAs for E-cadherin, vimentin, SDF-1 $\alpha$ and CXCR4 in Snail over-expressing (OM-1SNA1, OM-1SNA2) and control (OM-1pcD1, OM-1pcD2) clones. (C) OM-1pcD1 (a), OM-1SNA1 (b), and HOC313 (c) cells were stained with mouse anti-human CXCR4 antibody and visualized by FITC-conjugated antimouse IgG secondary antibody. (D) The migratory behavior of OM-1pcD1 (a, d), OM-1SNA1 (b, e), and HOC313 (c, f) cells was analyzed in an in vitro wound model. Photographs of culture cells were taken under a phase-contrast microscope in a wound healing assay performed at a magnification of x100. Photographs were taken just after incision (a-c) and $24 \mathrm{~h}$ post-incision (d-f).

expressing clones of OM-1SNA1 and OM-1SNA2, and control pcDNA3-transfected clones OM-1pcD1 and OM-1pcD2, have been described previously $(19,26,27)$. HOC719-PE and HOC719-NE cells were isolated from HOC719 cells expressing E-cadherin heterogeneously (19). All cells were cultured at $37^{\circ} \mathrm{C}$ in a humidified atmosphere of $5 \% \mathrm{CO}_{2}$ in air and maintained with DMEM (Sigma, St. Louis, MO, USA) supplemented with $10 \%$ fetal bovine serum (Sigma).

Immunofluorescent staining. Cells cultured on Lab-Tek II Chamber Slides (Nalge Nunc, Tokyo, Japan) were fixed with $4 \%$ paraformaldehyde and treated with $0.1 \%$ Triton $\mathrm{X}-100$ for $5 \mathrm{~min}$, PBS containing 1\% bovine serum albumin (BSA) for $30 \mathrm{~min}$, and a 1:200 dilution of anti-human CXCR4 monoclonal antibody (R\&D Systems, Minneapolis, MN, USA) in PBS containing $1 \% \mathrm{BSA}$ at $4^{\circ} \mathrm{C}$ overnight. Detection of CXCR4 protein was performed using 1:1000 dilutions of
FITC-labeled anti-mouse IgG (Dako, Kyoto, Japan). Vectashield (Vector Laboratories, Burlingame, CA, USA) was used as a mounting medium. Images were captured using an Optiphot-2 (Nikon, Tokyo, Japan) configured with fluorescent excitation filters at $800 \mathrm{~nm}$.

Reverse transcriptase-polymerase chain reaction ( $R T-P C R)$. Total-RNA was isolated from the cells using TRIzol (Invitrogen, Carlsbad, CA, USA). RT-PCR analysis was performed as described previously (19). The RNA samples were first treated with deoxyribonuclease I (Invitrogen) and converted into cDNA using random hexamer primers and reverse transcriptase (Invitrogen). PCR consisting of 30 cycles of denaturing at $94^{\circ} \mathrm{C}$ for $30 \mathrm{sec}$, annealing for $30 \mathrm{sec}$, and extension at $72^{\circ} \mathrm{C}$ for 1 min was carried out using PCR MASTER (Boehringer Mannheim GmbH, Germany). Amplified products were analyzed on $1.8 \%$ agarose gels. The 
A

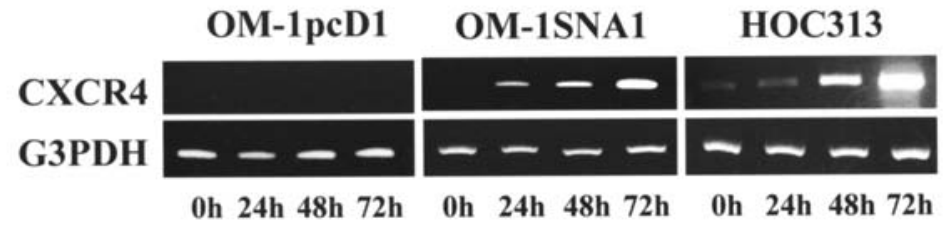

B
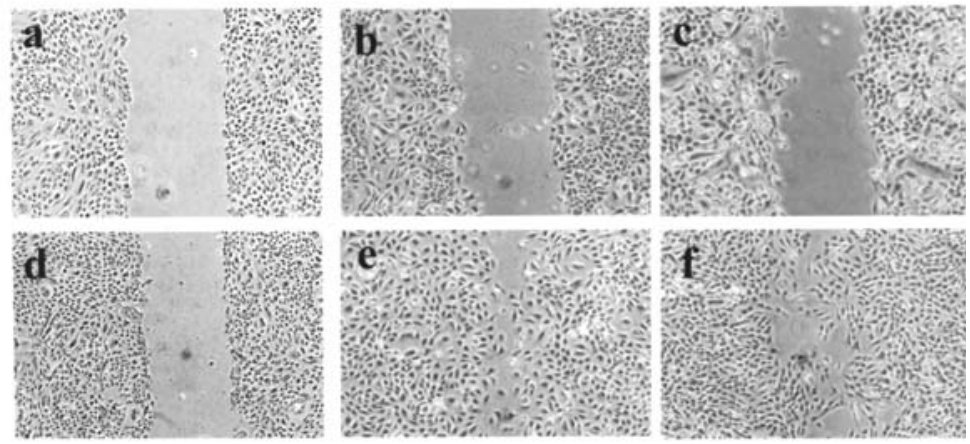

Figure 2. Effects of SDF-1 $\alpha$ on CXCR4 expression in SCC cells. (A) CXCR4 expression in OM-1pcD1, OM-1SNA1 and HOC313 cells treated with 50 ng/ml SDF-1 $\alpha$ for the indicated times. Total-RNAs were isolated from SCC cells and analyzed by RT-PCR. (B) The migratory behavior of OM-1pcD1 (a, d), OM-1SNA1 (b, e), and HOC313 (c, f) cells cultured with $50 \mathrm{ng} / \mathrm{ml}$ SDF-1 $\alpha$ was analyzed in an in vitro wound model. Photographs of culture cells were taken under a phase-contrast microscope in a wound healing assay performed at a magnification of $\mathrm{x} 100$. Photographs were taken just after incision (a-c) and $24 \mathrm{~h}$ post-incision (d-f).

product size, annealing temperature, and primer sequences for SDF- $1 \alpha$ and CXCR4 were: SDF- $1 \alpha, 239$ bp, $58^{\circ} \mathrm{C}, 5^{\prime}$-tgaa cgccaaggtcgtggtcgtg-3' (forward), 5'-ctccaggtactcetgaatccac-3' (reverse); CXCR4, 343 bp, $58^{\circ} \mathrm{C}, 5^{\prime}$-ctggtattgtcatcctgtcctgc- $3^{\prime}$ (forward), 5'-tggaccctctgctcacagaggtg-3' (reverse). The primers for E-cadherin, vimentin, and glyceraldehyde-3phosphate dehydrogenase (G3PDH) were previously described $(22,26,27)$. All primers were obtained from Hokkaido System Science Co., Ltd. (Sapporo, Japan).

Wound healing assay. Cells were seeded in 6-well culture dishes at $3 \times 10^{5}$ cells per well and incubated until confluent. After confluence, SDF- $1 \alpha$ and TGF- $\beta 1$ were added to the medium for $48 \mathrm{~h}$. A wound was incised with a pipette tip in the central area of the confluent culture on the dish. Detached cells were removed carefully with PBS and migrated cells in wound areas were observed utilizing a phase-contrast microscope.

\section{Results}

Expression of SDF-1 $\alpha$ and migratory activity in SCC cells with a mesenchymal phenotype. Expressions of SDF-1 $\alpha$ and its receptor, CXCR4, were analyzed in cells with a cuboidal morphology and E-cadherin expression (OM-1 and HOC719PE) and cells with a spindle morphology, loss of E-cadherin, and strong expression of vimentin and Snail (HOC719-NE, HOC313) $(26,27)$. RT-PCR analysis indicated strong expressions of SDF- $1 \alpha$ and CXCR4 in HOC719-NE and HOC313 cells but not in OM-1 and HOC719-PE cells (Fig. 1A). Snail over-expressing OM-1 cells, OM-1SNA1 and OM-1SNA2, showed the down-regulation of E-cadherin and up-regulation of vimentin expression, as previously described (26). Increased expression of SDF- $1 \alpha$ but not CXCR4, was observed in OM-1SNA1 and OM-1SNA2 cells (Fig. 1B). Immunofluorescent staining using a monoclonal antibody showed a strong CXCR4 expression on the cell surface in HOC313 cells (Fig. 1C-c), whereas no significant fluorescence staining was detected in OM-1pcD1 cells (Fig. 1C-a) and OM-1SNA1 cells (Fig. 1C-b). In a wound healing assay, HOC313 (Fig. 1D-f), but not OM-1pcD1 (Fig. 1D-d) cells, were detected in the wound area $24 \mathrm{~h}$ post-incision. Increased migratory activity was detected in OM-1SNA1 (Fig. 1D-e) compared to OM-1pcD1 (Fig. 1D-d) cells. OM-1SNA1 and HOC313 cells moved to the wounded area without the formation of cell-tocell contact.

Increased CXCR4 expression and cell migration by SDF-1a in SCC cells with a mesenchymal phenotype. Cells were cultured with $50 \mathrm{ng} / \mathrm{ml}$ of SDF- $1 \alpha$ for $72 \mathrm{~h}$ and CXCR4 expression was analyzed (Fig. 2A). SDF-1 $\alpha$ induced CXCR4 expression in OM-1SNA1 and HOC 313 cells but not in OM-1pcD1 cells. Treatment with $50 \mathrm{ng} / \mathrm{ml}$ of SDF- $1 \alpha$ for $24 \mathrm{~h}$ enhanced the migratory properties of OM-1SNA1 (Fig. 2B-e) and HOC313 (Fig. 2B-f) cells but not those of OM-1pcD1 (Fig. 2B-d) cells.

Increased CXCR4 expression and cell migration by TGF- $\beta 1$ in SCC cells with a mesenchymal phenotype. Cells were cultured with $2 \mathrm{ng} / \mathrm{ml}$ of TGF- $\beta 1$ for $72 \mathrm{~h}$ and the expressions of SDF- $1 \alpha$ and CXCR4 were analyzed (Fig. 3A). TGF- $\beta 1$ induced CXCR4 expression in OM-1SNA1 and HOC313 cells, but not in OM-1pcD1 cells. However, SDF-1 $\alpha$ expression was induced by TGF- 31 in all OM1-SNA1, OM-1pcD1, and 
A

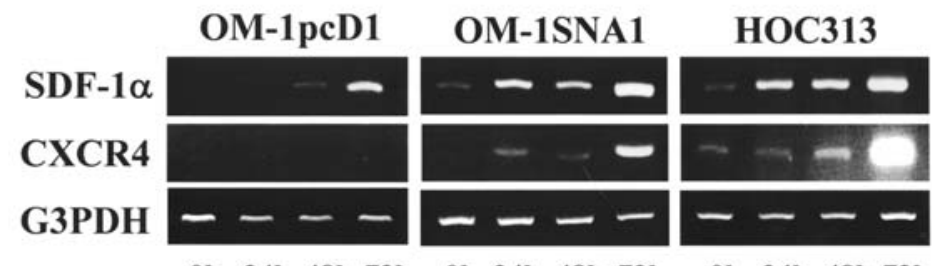

0h 24 h 48 h 72 h 0 h 24 h 48 h 72 h 0 h 24 h 48 h $72 h$

B

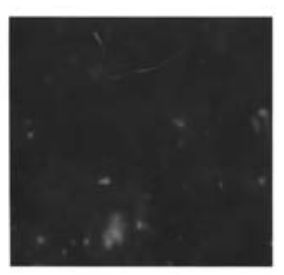

a

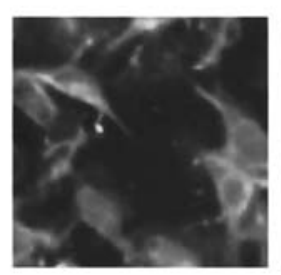

b

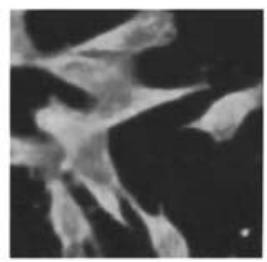

c

C
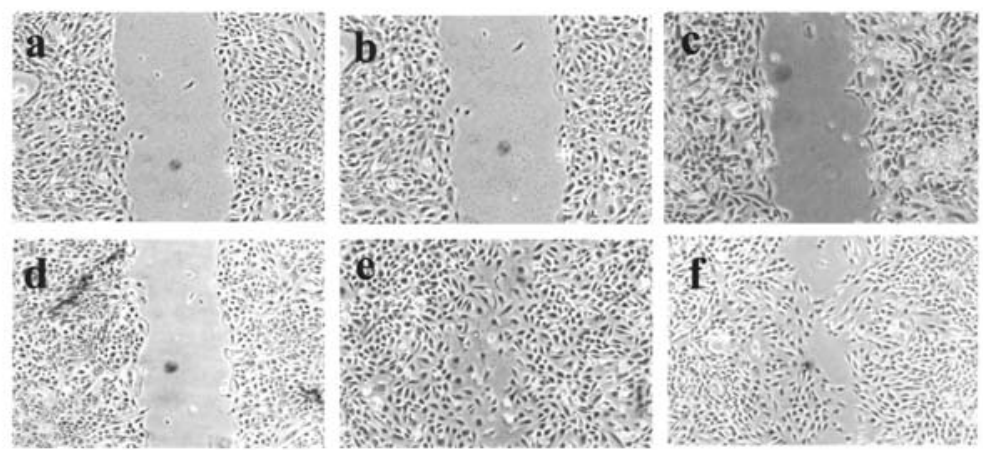

Figure 3. Effects of TGF-ß1 on SDF-1 $\alpha$ and CXCR4 expression in SCC cells. (A) Expression of mRNAs for SDF-1 $\alpha$ and CXCR4 in OM-1pcD1, OM1SNA1, and HOC313 cells cultured with $2 \mathrm{ng} / \mathrm{ml}$ TGF-31 for the indicated times. (B) OM-1pcD1 (a), OM-1SNA1 (b), and HOC313 (c) cells were stained with mouse anti-human CXCR4 antibody and visualized by FITC-conjugated anti-mouse IgG secondary antibody. Before staining, SCC cells were cultured with TGF- 31 for $72 \mathrm{~h}$. (C) The migratory behavior of OM-1pcD1 (a, d), OM-1SNA1 (b, e), and HOC313 (c, f) cells cultured with 2 ng/ml TGF-ß1 was analyzed in an in vitro wound model. Photographs of culture cells were taken under a phase-contrast microscope in a wound healing assay performed at a magnification of x100. Photographs were taken just after incision (a-c) and 24 h post-incision (d-f).

HOC313 cells. In immunofluorescent staining, treatment with TGF- 31 for $72 \mathrm{~h}$ resulted in increased CXCR4 expression in OM-1SNA1 and HOC313 cells, but not OM-1pcD1 cells, similarly to the results in Fig. 3A (Fig. 3B). In the wound healing assay, treatment with TGF- 11 for $24 \mathrm{~h}$ further enhanced the migratory properties of OM-1SNA1 (Fig. 3C-e) and HOC313 (Fig. 3C-f) cells.

\section{Discussion}

In previous studies, we showed that OM-1 and HOC719-PE cells had a cuboidal cell morphology with E-cadherin expression, and HOC719-NE and HOC313 cells showed a spindle cell morphology with a loss of E-cadherin and strong expression of vimentin, MMP-2, and Snail (19,26-28). We also reported that Snail over-expression and TGF- $\$ 1$ treatment in SCC cells with an epithelial phenotype resulted in a change to the spindle cell morphology and down-regulation of E-cadherin expression (28). In the present study, we showed strong expressions of SDF- $1 \alpha$ and CXCR 4 and migratory activity in HOC719-NE and HOC313 cells exhibiting the spindle morphology, but not in OM-1 and HOC719-PE cells with cuboidal shapes. Over-expression of Snail in OM-1 cells resulted in a change to the spindle morphology and the upregulation of SDF- $1 \alpha$ expression accompanied with enhanced migratory activity. Treatment with SDF- $1 \alpha$ induced CXCR 4 expression in Snail over-expressing and HOC313 cells but not in control cells. TGF- $\$ 1$ also induced CXCR4 expression in these cells. Furthermore, SDF-1 $\alpha$ expression in all SCC cells was induced by TGF- $\beta 1$. Strong migratory activity was detected in HOC313 and OM-1SNA1 cells, and both SDF-1 $\alpha$ and TGF- $\beta 1$ further promoted the migratory properties of these cells.

SDF- $1 \alpha$ has been reported to increase the migratory activity of cells depending on their expression of CXCR4 $(29,30)$. The migration induced by SDF-1 $\alpha$ was mediated 
through Akt activation in epithelioid carcinoma cells (31). Perissinotto et al reported that a specific inhibitor of the CXCR4 receptor completely inhibited lung metastasis in a mouse transplantation model and suggested that CXCR4 was involved in the metastatic process of osteosarcoma cells (32). Muller et al reported high levels of CXCR4 expression in invasive ductal carcinoma but not normal mammary gland ductal cells using immunostaining (5). They also mentioned a strong CXCR4 expression in tumor cells in lymph node and distant metastases of the lung and liver. Furthermore, Li et al reported that expression levels of CXCR4 were correlated with the overall survival rate in breast cancer (33). Chen et al observed that TGF- $\beta 1$ affected CXCR4 expression through the stimulation of SDF- $1 \alpha$ and ERK1/2 phosphorylation in human monocyte-derived macrophages (34). On the contrary, secreted TGF- $\beta 1$ from cholangiocarcinoma cells decreased the expression of SDF-1 in fibroblasts and then inhibited the invasion of cholangiocarcinoma cells (35). We previously reported that Snail expression was strongly increased by TGF- $\beta 1$ in highly-invasive SCC cells with the mesenchymal phenotype, but not epithelial phenotype. In the present study, we suggested that the regulation of CXCR4 expression was different with regard to the condition of EMT in SCC cells. Further analysis concerning the regulation of CXCR4 expression accompanying EMT might be useful for the treatment of metastatic lymph nodes of SCC.

\section{References}

1. Rollins BJ: Chemokines. Blood 90: 909-928, 1997.

2. Rossi D and Zlotnik A: The biology of chemokines and their receptors. Annu Rev Immunol 18: 217-242, 2000.

3. Zlotnik A and Yoshie O: Chemokines: a new classification system and their role in immunity. Immunity 12: 121-127, 2000.

4. Hosokawa Y, Hosokawa I, Ozaki K, Nakae H, Murakami K, Miyake Y and Matsuo T: CXCL12 and CXCR4 expression by human gingival fibroblasts in periodontal disease. Clin Exp Immunol 141: 467-474, 2005.

5. Muller A, Homey B, Soto H, Ge N, Catron D, Buchanan ME, McClanahan T, Murphy E, Yuan W, Wagner SN, Barrera JL, Mohar A, Verastegui E and Zlotnik A: Involvement of chemokine receptors in breast cancer metastasis. Nature 410: 50-56, 2001.

6. Taichman RS, Cooper C, Keller ET, Pienta KJ, Taichman NS and McCauley LK: Use of the stromal cell-derived factor-1/ CXCR4 pathway in prostate cancer metastasis to bone. Cancer Res 62: 1832-1837, 2002.

7. Scotton CJ, Wilson JL, Milliken D, Stamp G and Balkwill FR: Epithelial cancer cell migration: a role for chemokine receptors? Cancer Res 61: 4961-4965, 2001.

8. Uchida D, Begum NM, Almofti A, Nakashiro K, Kawamata H, Tateishi Y, Hamakawa H, Yoshida $\mathrm{H}$ and Sato M: Possible role for stromal-cell-derived factor-1/CXCR4 signaling on lymph node metastasis of oral squamous cell carcinoma. Exp Cell Res 290: 289-302, 2003.

9. Bertolini F, Dell'Agnola C, Mancuso P, Rabascio C, Burlini A, Monestiroli S, Gobbi A, Pruneri G and Martinelli G: CXCR4 neutralization, a novel therapeutic approach for non-Hodgkin's lymphoma. Cancer Res 62: 3106-3112, 2002.

10. Murakami T, Maki W, Cardones AR, Fang H, Tun Kyi A, Nestle FO and Hwang ST: Expression of CXC chemokine receptor-4 enhances the pulmonary metastatic potential of murine B16 melanoma cells. Cancer Res 62: 7328-7334, 2002.

11. Kucia M, Jankowski K, Reca R, Wysoczynski M, Bandura L, Allendorf DJ, Zhang J, Ratajczak J and Ratajczak MZ: CXCR4SDF-1 signaling, locomotion, chemotaxis and adhesion. J Mol Histol 35: 233-245, 2004.
12. Savagner P: Leaving the neighborhood: molecular mechanisms involved during epithelial-mesenchymal transition. Bioessays 23: 912-923, 2001.

13. Shook D and Keller R: Mechanisms, mechanics and function of epithelial-mesenchymal transitions in early development. Mech Dev 120: 1351-1383, 2003.

14. Thiery JP: Epithelial-mesenchymal transitions in tumor progression. Nat Rev Cancer 2: 442-454, 2002.

15. Huber MA, Kraut $\mathrm{N}$ and Beug H: Molecular requirements for epithelial-mesenchymal transition during tumor progression. Curr Opin Cell Biol 17: 548-558, 2005.

16. Frixen UH, Behrens J, Sachs M, Eberle G, Voss B, Warda A, Lochner D and Birchmeier W: E-cadherin-mediated cell-cell adhesion prevents invasiveness of human carcinoma cells. J Cell Biol 113: 173-185, 1991.

17. Oka H, Shiozaki H, Kobayashi K, et al: Expression of E-cadherin cell adhesion molecules in human breast cancer tissues and its relationship to metastasis. Cancer Res 53: 1696-1701, 1993.

18. Cano A, Perez-Moreno MA, Rodrigo I, Lacascio A, Blanco MJ, Del Barrio MG, Portillo F and Nieto MA: The transcriptional factor Snail controls epithelial-mesenchymal transitions by repressing E-cadherin expression. Nat Cell Biol 2: 76-83, 2000

19. Yokoyama K, Kamata N, Hayashi E, Hoteiya T, Ueda N, Fujimoto R and Nagayama M: Reverse correlation of E-cadherin and snail expression in oral squamous cell carcinoma cells in vitro. Oral Oncol 37: 65-71, 2001.

20. Eger A, Aigner K, Sonderegger S, Dampier B, Oehler B, Schreiber M, Berx G, Cano A, Beug H and Foisner R: DeltaEF1 is a transcriptional repressor of E-cadherin and regulates epithelial plasticity in breast cancer cells. Oncogene 24: 2375$2385,2005$.

21. Comijn J, Berx G, Vermassen P, Verschueren K, van Grunsven L, Bruyneel E, Mareel M, Huylebroeck D and van Roy F: The twohanded E-box binding zinc finger protein SIP1 down-regulates E-cadherin and induces invasion. Mol Cell 7: 1267-1278, 2001.

22. Perez-Moreno MA, Locascio A, Rodrigo I, Dhondt G, Portillo F, Nieto MA and Cano A: A new role for E12/E47 in the repression of E-cadherin expression and epithelial-mesenchymal transitions. J Biol Chem 276: 27424-27431, 2001.

23. Miettinen PJ, Ebner R, Lopez AR and Derynck R: TGF-beta induced transdifferentiation of mammary epithelial cells to mesenchymal cells: involvement of type I receptors. J Cell Biol 127: 2021-2036, 1994.

24. Peinado H, Quintanilla $M$ and Cano A: Transforming growth factor beta-1 induces snail transcription factor in epithelial cell lines: mechanisms for epithelial mesenchymal transitions. J Biol Chem 278: 21113-21123, 2003.

25. Zavadil $\mathrm{J}$ and Bottinger EP: TGF-beta and epithelial-tomesenchymal transitions. Oncogene 24: 5764-5774, 2005.

26. Taki M, Kamata N, Yokoyama K, Fujimoto R, Tsutsumi S and Nagayama M: Down-regulation of Wnt-4 and up-regulation of Wnt-5a expression by epithelial-mesenchymal transition in human squamous carcinoma cells. Cancer Sci 94: 593-597, 2003.

27. Yokoyama K, Kamata N, Fujimoto R, Tsutsumi S, Tomonari M, Taki M, Hosokawa $\mathrm{H}$ and Nagayama $\mathrm{M}$ : Increased invasion and matrix metalloproteinase-2 expression by Snail-induced mesenchymal transition in squamous cell carcinomas. Int $\mathbf{J}$ Oncol 22: 891-898, 2003.

28. Taki M, Verschueren K, Yokoyama K, Nagayama M and Kamata N: Involvement of Ets-1 transcription factor in inducing matrix metalloproteinase- 2 expression by epithelial mesenchymal transition in human squamous carcinoma cells. Int J Oncol 28: 487-496, 2006.

29. Kayali AG, van Gunst K, Campbell IL, Stotland A, Kritzik M, Liu G, Flodstrom-Tullberg M, Zhang YQ and Sarvetnick N: The stromal cell-derived factor-1a/CXCR4 ligand-receptor axis is critical for progenitor survival and migration in the pancreas. J Cell Biol 163: 859-869, 2003

30. Singh S, Singh UP, Grizzle WE and Lillard JW Jr: CXCL12CXCR4 interactions modulate prostate cancer cell migration, metalloproteinase expression and invasion. Lab Invest 84: 1666-1676, 2004

31. Peng SB, Peek V, Zhai Y, Paul DC, Lou Q, Xia X, Eessalu T, Kohn W and Tang S: Akt activation, but not extracellular signal-regulated kinase activation, is required for SDF-1 $1 \alpha /$ CXCR4-mediated migration of epitheloid carcinoma cells. Mol Cancer Res 3: 227-236, 2005. 
32. Perissinotto E, Cavalloni G, Leone F, Fonsato V, Mitola S, Grignani G, Surrenti N, Sangiolo D, Bussolino F, Piacibello W and Aglietta M: Involvement of chemokine receptor 4/stromal cell-derived factor 1 system during osteosarcoma tumor progression. Clin Cancer Res 11: 490-497, 2005.

33. Li YM, Pan Y, Wei Y, Cheng X, Zhou BP, Tan M, Zhou X, Xia W, Hortobagyi GN, Yu D and Hung MC: Up-regulation of CXCR4 is essential for HER2-mediated tumor metastasis. Cancer Cell 6: 459-469, 2004.

34. Chen S, Tuttle DL, Oshier JT, Knot HJ, Streit WJ, Goodenow MM and Harrison JK: Transforming growth factor-betal increases CXCR4 expression, stromal-derived factor-1alpha-stimulated signaling and human immunodeficiency virus- 1 entry in human monocyte-derived macrophages. Immunology 114: 565-574, 2005.
35. Ohira S, Itatsu K, Sasaki M, Harada K, Sato Y, Zen Y, Ishikawa A, Oda K, Nagasaka T, Nimura Y and Nakanuma Y: Local balance of transforming growth factor-betal secreted from cholangiocarcinoma cells and stromal-derived factor-1 secreted from stromla fibroblasts is a factor involved in invasion of cholangiocarcinoma. Pathol Int 56: 381-389, 2006. 